\title{
Do long-short speculators destabilize commodity futures markets?
}

Article

Accepted Version

Miffre, J. and Brooks, C. (2013) Do long-short speculators destabilize commodity futures markets? International Review of Financial Analysis, 30. pp. 230-240. ISSN 1057-5219 doi: https://doi.org/10.1016/j.irfa.2013.09.002 Available at https://centaur.reading.ac.uk/36099/

It is advisable to refer to the publisher's version if you intend to cite from the work. See Guidance on citing.

To link to this article DOI: http://dx.doi.org/10.1016/j.irfa.2013.09.002

Publisher: Elsevier

All outputs in CentAUR are protected by Intellectual Property Rights law, including copyright law. Copyright and IPR is retained by the creators or other copyright holders. Terms and conditions for use of this material are defined in the End User Agreement.

\section{www.reading.ac.uk/centaur}

\section{CentAUR}

Central Archive at the University of Reading

Reading's research outputs online 
NOTICE: this is the author's version of a work that was accepted for publication in the International Review of Financial Analysis. Changes resulting from the publishing process, such as peer review, editing, corrections, structural formatting, and other quality control mechanisms may not be reflected in this document. Changes may have been made to this work since it was submitted for publication. A definitive version was subsequently published in the International Review of Financial Analysis, 30 (2013) DOI: 10.1016/j.irfa.2013.09.002 


\title{
Do Long-Short Speculators Destabilize Commodity Futures Markets?
}

\author{
Joëlle Miffre* and Chris Brooks**
}

\begin{abstract}
This paper contributes to the debate on the effects of the financialization of commodity futures markets by studying the conditional volatility of long-short commodity portfolios and their conditional correlations with traditional assets (stocks and bonds). Using several groups of trading strategies that hedge fund managers are known to implement, we show that long-short speculators do not cause changes in the volatilities of the portfolios they hold or changes in the conditional correlations between these portfolios and traditional assets. Thus calls for increased regulation of commodity money managers are, at this stage, premature. Additionally, long-short speculators can take comfort in knowing that their trades do not alter the risk and diversification properties of their portfolios.
\end{abstract}

Keywords: Financialization, Commodity markets, Speculators, Volatility, Correlation JEL classifications: G11, G13

* Professor of Finance at EDHEC Business School and member of the EDHEC-Risk Institute. ** Professor of Finance and Director of Research, ICMA Centre, Reading.

Address for correspondence: EDHEC Business School, 393 Promenade des Anglais, 06202 Nice, France. Tel. +33 (0)4931832 55. E-mail: Joelle.Miffre@ edhec.edu.

We would like to thank F. Ducoulombier, L. Martellini, O. Johnson and his colleagues at the Chicago Mercantile Exchange Group, H. Till, and two anonymous referees for useful comments. The first author acknowledges financial support from the CME Group. The contents of this paper do not necessarily reflect the views of the CME Group. 


\section{Introduction}

The surge in commodity investing and its potential impact on prices (or the so-called "financialization" of commodity markets) has been the subject of an intense debate, both in the political and regulatory arenas and in academic circles. Commodity futures became increasingly desired by investors due to their equity-like returns, inflation hedging and diversification benefits (Gorton and Rouwenhorst, 2006; Erb and Harvey, 2006), resulting in substantial increases in trading volumes and open interest (Irwin and Sanders, 2012). It has been reported that volatility was greater in the late 2000's than in the past and this may increase hedging margin call costs and diminish the willingness of commodity purchasers to engage in forward purchases, thereby reducing farmers' chances of ensuring price certainty (Hailu and Weersink, 2010).

But did commodity investors damage the price-setting mechanism, driving commodity prices away from their fundamentals? This view has been repeatedly expressed by politicians and in the media. The 2009 Staff Report by the U.S. Senate Permanent Subcommittee on Investigation argues in favor of this proposition, stating that a rise in the long positions of commodity index traders (CITs) caused a commodity price bubble. ${ }^{1}$ In April 2012, Finance Watch further argues that excessive speculation and its positive impact on prices led to food riots and social unrest, preventing the risk transfer that usually takes place in commodity futures markets between hedgers and speculators. ${ }^{2}$ In an attempt to curb speculation and volatility from occurring in the future, Finance Watch calls for greater transparency in hedgers' and speculators' positions, the definition of stringent position limits for speculators and a ban on commodity index instruments.

This article adds to the debate on the financialization of commodity futures markets by using a novel approach to testing whether long-short commodity investors have an impact on the volatility of the portfolios they hold and on the correlation between their long-short commodity portfolios and traditional assets (S\&P500 composite index and Barclays Capital US Aggregate bond index). The large majority of research to examine the impact of speculators on commodity markets focuses on percentage price changes, rather than volatility or cross-market correlations.

\footnotetext{
${ }^{1}$ The report entitled "Excessive Speculation in the Wheat Market" is available at http://www.hsgac.senate.gov/subcommittees/investigations/reports

${ }^{2}$ Finance Watch, 2012, Investing not betting, Making financial markets serve society, A position paper on MiFID 2/MiFIR, April.
} 
In addition, while the literature for the most part centers on the trade impact of net-long CITs, we study the role of long-short traders (such as commodity trading advisors (CTAs) or more generally hedge funds), a topic that is solely addressed in Büyükşahin and Robe (2010) and Brunetti et al. (2011). The novelty of our approach relative to these two articles comes from the fact that we use a battery of strategies that hedge funds are known to follow (such as momentum and term structure investing) and then test the proposition that the trading of these long-short speculators Granger-causes (see Granger, 1969) a change in the volatility of their portfolios or a change in cross-market correlations. To our knowledge we are the first to examine such strategies in the context of their impact on commodity market price variability and correlations. Another advantage of our approach is that, relative to previous studies, it enables us to employ a much larger cross section over a longer time span. We are also able to test the hypothesis that longshort investors may be destroying through their actions the very risk diversification they sought out in the first instance. A finding that long-short commodity traders increase volatility and crossmarket linkages could also legitimate popular claims for increased regulation.

Our results indicate that speculators have no significant impact on volatility or cross-market correlation. This conclusion holds irrespective of whether speculators are labeled as "noncommercial" in the CFTC (Commodity Futures Trading Commission) Commitment of Traders (COT) report or "professional money managers" (i.e., CTAs, commodity pool operators (CPOs) and hedge funds) in the CFTC disaggregated COT report. It follows that calls for increased regulation of commodity money managers are, at this stage, premature: they are unlikely to prevent volatility from rising again in the future. Our results also indicate that long-short managers can take comfort in the knowledge that their trades do not distort volatility and correlation and thus do not alter the risk and diversification properties of their portfolios.

The remainder of this paper is structured as follows. Section 2 sets up the debate on the financialization of commodity futures markets from an academic perspective. Section 3 presents the dataset we use. Section 4 introduces the methodologies employed to capture the returns earned by long-short speculators in commodity futures markets, the conditional volatility of their portfolios and the conditional correlation between their returns and traditional assets. Section 4 also highlights the methodology used to test whether changes in the positions of speculators Granger-cause changes in conditional volatility or in conditional correlations. Section 5 discusses our results and finally section 6 concludes. 


\section{Where does the debate stand in academic circles?}

The academic debate as to whether the financialization of commodity markets is responsible for the observed volatility of commodity prices has been intense and is still on-going. The discussion centers around the potentially destabilizing role of net-long CITs and long-short speculators (such as CTAs) on commodity futures prices.

The evidence from the perspective of CITs is mixed. On one side, using various approaches including Granger-causality tests, Irwin et al. (2009) and Stoll and Whaley (2010) show that CITs had no role in the price rises observed in 2006-2008. Sanders and Irwin (2010a) further argue that in four grain futures markets, the rise in the participation of index traders took place two to three years before the price bubble observed in 2007-2008, a result that clears CITs of any accountability for the bubble. Likewise, Sanders and Irwin (2011b) conclude that swap dealers, who are considered as CITs, far from destabilizing markets, Granger-cause decreases in market volatility. Gilbert and Morgan (2010) further argue that there is evidence that the prices of foodstuffs actually became more stable during the 1990s and 2000s at the same time as the activities of CITs increased. According to this literature, rather than CITs, it is fundamentals and supply and demand imbalances that are to blame for the price bubble. ${ }^{3}$

On the other hand, there are several noteworthy studies arguing that CITs did cause the 20072008 price spike by increasing correlations across indexed commodity futures. Gilbert (2010), in particular, argues that index activity was driven in part by a belief that economic growth in China would increase demand for numerous commodities, and in part by a desire to hedge falls in the US dollar. Likewise, Tang and Xiong (2012) see index traders as more influential on price determination than other factors such as a weakening in the US dollar, an increase in the demand for indexed commodities, the financial crisis that followed Lehman Brothers' demise, a sudden rise in inflation or the widespread use of biofuel. As a result of the financialization of commodity markets via commodity index funds, the prices of indexed commodities rose in tandem, causing

\footnotetext{
${ }^{3}$ For example, Hamilton (2009) blames the stagnation in global supply and the rapid growth in global demand for the oil price shock of 2007-2008. Korniotis (2009) relates the sharp rise in spot metal prices in 2003-2004 to economic fundamentals such as rising demand and consumption or falling production and inventories. Calvo-Gonzales et al. (2010), examining a very long panel of commodity prices back to the end of the eighteenth century, argue that price volatility has risen and fallen enormously over the past century or so along with changes in fundamentals.
} 
an increase in their correlations. Relatedly, Cheng et al. (2012) argue that in times of distress, CITs, by reducing their net long exposures, fail to provide the insurance that short hedgers demand.

Another strand of research - which is perhaps more related to our article - focuses on whether long-short investors are to blame for the observed price changes. Here too, the conclusions thus far are rather inconclusive. Tests for excessive speculation support the idea that speculation rose merely as a response to a rise in hedging demand (Till, 2009; Sanders et al., 2010) and thus that long-short speculators are not to blame for excessive price impact. Likewise, Brunetti et al. (2011) test whether changes in the net positions of hedge funds in three commodities (corn, crude oil and natural gas) Granger-cause volatility. They conclude that such funds, far from destabilizing markets, actually decrease volatility. Thus these articles refute the idea that longshort traders have harmful impact. Rather, they act as liquidity and insurance providers, being beneficial to markets overall. This conclusion ought to be viewed with caution, however, in the light of Büyükşahin and Robe (2010), who find hedge funds active in both equity and commodity futures markets responsible for the rise in conditional correlations between commodity and stock indices observed since 2008.

Therefore, the empirical evidence on whether long-short speculators have a destabilizing role is mixed. It is also not obvious from a theoretical perspective whether speculators move prices away from equilibrium. The traditional view, as put forward by Friedman (1953), is that speculators (or rational news traders) stabilize prices: by buying low and selling high, they bring prices closer to fundamentals. Yet, De Long et al. (1990) bring forward a theoretical model showing that rational news traders, by anticipating the price impact of trend followers (or positive feedback traders), actually end up destabilizing markets. In their model, rational speculators, in anticipation of the forthcoming buy/sell orders of trend followers, increase their long/short positions today in the hope of earning higher returns tomorrow. As a result, far from stabilizing prices, they end up setting price trends and deterring short-term prices away from fundamentals. It is thus not obvious from a theoretical standpoint whether long-short speculators stabilize markets.

Like Büyükşahin and Robe (2010) and Brunetti et al. (2011), this paper tests whether long-short speculators destabilize commodity futures markets by increasing volatility or cross-market correlations. Unlike the aforementioned articles, however, we use a novel approach that consists of first, modeling the returns that long-short speculators earn using a battery of strategies that 
they are known to follow and then, explicitly testing whether their trading has any impact on the volatility of the portfolios they hold or on cross-market correlations. This approach enables us to test the robustness of the conclusions of Büyükşahin and Robe (2010) and Brunetti et al. (2011) to the use of a different methodology, ${ }^{4}$ while considering a much larger cross-section and a longer time span (1992-2011 versus 2000-2010 in Büyükşahin and Robe, 2010 or 2005-2009 in Brunetti et al., 2011). We examine a range of trading strategies that hedge fund managers employ, rather than just aggregate net positions. Therefore, our findings are not only of relevance to the debate about whether speculators have an effect on commodity futures markets that disadvantages producers and consumers, we can also identify whether hedge funds damage the very property of commodity returns that made the asset class attractive investments in the first place - namely their low correlations with other asset classes.

\section{Data}

We obtain data on a sample of 27 commodity futures price series for the period 2 October 1992 to 25 March 2011 from Thomson Datastream. These series are the following commodity futures: random length lumber, five metals, five energy futures, four livestock futures, and 12 agricultural futures. We employ a wider range of commodities than that typically used in the literature. ${ }^{5}$ Our choice of series, as well as their frequency (weekly) and sample period, is dictated by the existence of information in the CFTC Commitment of Traders report on the positions of speculators and hedgers. The positions of commercial traders (hedgers) and non-commercial traders (speculators) are collected every Tuesday and made available to the public the following Friday. To construct a continuous futures pricing series, we assume that to avoid physically delivering the commodity, the nearby contract is held until the last Friday of one month prior to maturity and then investors roll their positions to switch into the second nearest contract. The

\footnotetext{
${ }^{4}$ Büyükşahin and Robe (2010) tests whether excess speculation (as measured by the T-index) has an impact on conditional correlation between the S\&P500 and the S\&P-GSCI. Our approach is more likely to detect an impact, if any, inasmuch as we test whether long-short speculators influence volatility and correlation with respect to their own commodity portfolios and not the market as a whole.

${ }^{5}$ Because of availability on CIT positions, Irwin et al. (2009), Irwin and Sanders (2011) and Sanders and Irwin (2011a, 2011b) focus on agriculture only. Büyükşahin and Robe (2010) cover 17 commodities; Brunetti et al. (2011) focus on 3 commodities.
} 
procedure is reiterated using the then second-nearest contract. Thus futures returns are always calculated using price changes on the same contract in a fashion that can be replicated by investors. The choice of nearest and second-nearest contracts (rather than employing all available contracts including the more distant ones) is to ensure that all are liquid. ${ }^{6}$ When the continuous pricing series is obtained, we compute continuously compounded $(\log )$ returns for use in all subsequent models and analysis.

Summary statistics for the commodity futures returns are given in Table 1. It is evident that, confirming Erb and Harvey's (2006) earlier observation, commodities did not perform well over the sample period when considered as individual investments, with both low average returns and high standard deviations. From 1992-2011, the average excess return across all commodity futures in our sample was almost exactly zero, but with a huge range around this figure. Ten commodities had negative average excess returns, while it was positive for the remaining seventeen. Electricity was by far the worst performer with average annualized excess returns of $25.7 \%$, while the best were copper, crude oil, palladium, platinum, silver, and soybean meal, all of which generated excess returns of $9-11 \%$ per annum.

Panel B of the table shows that the commodity indices did not do better than the typical behavior of the individual components, with average returns close to zero for an equally-weighted longonly portfolio and around 4\% for the Standard and Poor's Goldman Sachs Commodity Index (S\&P-GSCI), which is a production-weighted index of the prices of exchange-traded, liquid, physical commodity futures contracts and is heavily weighted towards oil.

The paper analyzes the evolution in the conditional correlations between long-short commodity portfolios and traditional assets. To represent the latter, we choose the S\&P-500 Composite Index and Barclays Capital US Aggregate Bond Index. To measure the risk-adjusted performance of the portfolios, we examine their Sharpe ratios. The Sharpe ratio of the S\&P-GSCI (0.2), despite

6 There is a slight inconsistency in that our construction of the continuous futures price series employs only the nearest and second nearest to maturity contracts but the hedging pressure involves an average over all maturity contracts. However, the COT only reports the aggregate open interest over all contract expirations and there is no way to split this into the nearest versus other contracts. In keeping with almost the entire literature dealing with futures contracts, however, we prefer to employ the nearest and next nearest contracts which are highly liquid; more distant contracts, by contrast, are much more thinly traded. Further results demonstrate that this inconsistency should not be a significant issue in practice since in most cases the front contract represents a very large part of the overall open interest. 
being considerably better than that of the equally-weighted portfolio $(0.05)$, is below that of the S\&P500 stock index (0.24) and well below that of an aggregate bond index (0.66). The Sharpe ratio of the S\&P500 index also exceeds that of 22 (out of 27) individual commodities.

\section{$<<$ Insert Table 1 around here $>>$}

To determine the liquidity of the commodity markets that we consider in this study, the two rightmost columns of Table 1 display the average open interest for each series. For most commodities in the sample, the markets appear to have sufficient depth, although this is not the case for electricity, pork bellies, random length lumber and rough rice. A lack of liquidity would have an impact upon the abilities of speculators to implement the strategies that we consider below. Therefore, in order to mitigate its effects, we specifically exclude the $25 \%$ of series with the lowest average open interest over the $R$ weeks immediately prior to portfolio formation. ${ }^{7}$

The CFTC classifies traders based on the sizes of their positions into those who are "reportable" and those who are "non-reportable." Reportable traders constitute $70 \%$ to $90 \%$ of the open interest in any given futures markets and are further recorded as "commercial" or "noncommercial." Commercial traders use commodity derivatives to hedge price risk. Noncommercial traders have no position in the underlying asset; they either take a long-only approach or speculate on an upcoming rise or fall in prices. ${ }^{8}$ Aside from declaring whether they are commercial (hedgers) or non-commercial (speculators), traders also have to report whether they are long or short. The evolution in the long and short positions of speculators (i.e., noncommercial traders) is pictured in Figure 1, where the plot is for the open interest of both long and short speculators averaged across our 27 commodities (on the left-hand side) and for the futures prices of the S\&P-GSCI (on the right-hand side). Two points are worth noting. First, the huge changes in the open interest of long speculators seem to parallel the dramatic ups and downs of the S\&P-GSCI over the 1992-2011 period. This gives credibility to the claim that the activities

\footnotetext{
${ }^{7}$ The problem is magnified in our case since we adopt equally-weighted portfolios in order to ensure that the strategies are well-diversified and are not effectively focused on just one or two commodities.

${ }^{8}$ We should note a potential issue, first identified by Ederington and Lee (2002), that trader designations may not be correct in some cases. In particular, as traders self-classify, there may be an incentive for speculators to specify that they are commercial hedgers and thus the latter category may include traders who should be in the former. Although there is no way of knowing how large this reporting bias is, it is unlikely to be huge as CFTC staff members routinely check declarations, reallocating traders to their rightful category if necessary.
} 
of speculators could have increased the volatility of the S\&P-GSCI. Second, both the long and short positions of speculators have risen sharply over the period 1992-2011, confirming that indeed there was an increase in the financialization of commodity futures markets.

$<$ Insert Figure 1 around here $>>$

We construct separate measures of hedging pressure for speculators and for hedgers, both based on the declarations of market participants summarized in the Commitment of Traders report. These measures are constructed by taking for the previous week the number of long positions as a proportion of the total number of long and short positions by non-commercial traders. ${ }^{9}$ So, for instance, a hedging pressure value of 0.3 for hedgers would imply that only $30 \%$ of hedgers were long over the immediately prior week and the remaining $70 \%$ were short and thus the market was backwardated. ${ }^{10}$ On the other hand, a value of 0.3 for speculators shows that $30 \%$ of speculators were long with the remaining $70 \%$ being short, indicative of a contangoed market. ${ }^{11}$

The hedging pressure measures thus defined are used in two ways. First, as in Basu and Miffre (2013), we use them as signals for sorting commodity futures into portfolios, where the returns of portfolios that buy backwardated commodities and sell contangoed commodities are deemed to replicate the returns that speculators earned over the period 1992-2011 for taking on price risk. Second, we use the hedging pressure measures to test whether commodity markets have become more volatile - and asset markets more integrated - under the actions of speculators. The idea here is to test whether changes in the hedging pressure of speculators Granger-cause changes in the

\footnotetext{
${ }^{9}$ Because hedging pressure is a ratio with open interest in both the numerator and denominator, the measure is invariant to changes in the specification of the individual contracts over time. Therefore, there is no need to adjust the COT data as in Bryant et al. (2006).

${ }^{10}$ Backwardation occurs when commodity producers are more prone to hedge than commodity consumers and processors. The then net short positions of hedgers lead to the intervention of net long speculators and thus to the rising price pattern typically associated with backwardation. In our setting, backwardation translates into low hedging pressure for hedgers and high hedging pressure for speculators.

${ }^{11}$ Contango arises when consumers and processors of a commodity outnumber producers. The then net long positions of hedgers lead to the intervention of net short speculators and to the falling price pattern typically linked to contango. In our setting, contango translates into high hedging pressure for hedgers and low hedging pressure for speculators.
} 
volatilities of the portfolios they hold or changes in the conditional return correlations between their portfolios and traditional assets.

\section{Methodology}

To mimic the trading behavior of long-short market participants, we implement a battery of longshort strategies that hedge fund managers are known to follow (Bhardwaj et al., 2008), where these strategies are based on momentum and term structure signals. We also replicate their trading behavior by looking at the positions they took (Basu and Miffre, 2013). In total we have eight strategies that are based on performance, roll-returns, the positions of hedgers or/and the positions of speculators. These rule-based strategies aim at systematically taking long positions in the commodities whose prices are expected to appreciate and short positions in the commodities whose prices are expected to depreciate. ${ }^{12}$ Sections 4.1 and 4.2 briefly summarize the methodologies used to implement these strategies. Section 4.3 then presents the techniques employed to model the conditional volatility of commodity portfolios and their conditional return correlations with traditional assets. Finally, Section 4.4 introduces the methodology employed to test whether changes in speculators' positions Granger-cause changes in volatility or changes in correlation.

\subsection{Momentum and Term Structure Strategies}

Further to the approaches documented in Erb and Harvey (2006) and Miffre and Rallis (2007), we construct momentum portfolios by taking long positions in the quintile of commodity futures having the highest average returns during the ranking period of $R$ weeks ("the winners") and short positions in the quintile of futures having the lowest returns over the same horizon ("the losers"). These positions are then retained for a holding period of $H$ weeks and are then rebalanced and a new set of portfolios are formed following the same procedure.

We construct term structure portfolios by taking long positions in the quintile of commodity futures having the best mean roll returns during the $R$-week ranking period and short positions in

${ }^{12}$ We remind the reader that each of the strategies described below are implemented on all commodities but omitting the $25 \%$ that have the lowest average open interest at the portfolio formation point. We adopt this filter to ensure liquidity in the instruments such that all of the strategies could have been implemented in a timely fashion and with acceptable transactions costs. 
the quintile of futures having the smallest mean roll returns over this horizon (see Erb and Harvey, 2006; Gorton and Rouwenhorst, 2006). We calculate the roll return as the nearby contract's log price less that of the second nearest. These positions are again retained for a holding period of $H$ weeks and are then rebalanced and new portfolios are formed following the same procedure.

We also adopt a combined strategy that results from a two-way sort on the momentum and term structure measures, following Fuertes et al. (2010). To first sort by momentum, our full sample is initially separated using $R$-week average returns into Winner and Loser portfolios each containing $50 \%$ of the available cross section. To then sort by term structure, we purchase the $40 \%$ of the Winner portfolio's constituents that have the greatest mean $R$-week roll returns and we sell the $40 \%$ of the Loser portfolio's constituents that have the lowest $R$-week roll returns. These long and short positions are retained for the following $H$ weeks. Since the implicit choice above to first sort on past return performance and then on roll returns was entirely arbitrary, we then repeat the two way sort procedure but now swapping the order of forming the portfolios.

\subsection{Hedging Pressure Strategies}

The next group of strategies we consider are based on hedging pressure and aim to replicate the reward that speculators would gain by assuming the price risk that hedgers want to offload - see Basu and Miffre (2013). We construct a portfolio that takes long positions in the quintile of most backwardated commodity futures for which hedgers had the lowest mean hedging pressure (i.e. where they were most net short) over an $R$-week portfolio formation period. We also construct a portfolio that takes short positions in the quintile of most contangoed commodity futures for which hedgers had the greatest mean hedging pressure (i.e. where they were most net long) over the same formation period. We then hold these long and short positions for the following $H$ weeks before the portfolios are rebalanced and a new set of portfolios is formed.

We also adopt long-short strategies based on the hedging pressure of speculators. We implement a long portfolio using the quintile of commodity futures for which speculators had the highest mean hedging pressure (i.e. they were most net long) over the $R$-week portfolio formation period. Similarly, we implement a short portfolio using the quintile of commodity futures for which speculators had the lowest mean hedging pressure (i.e. they were most net short) over the same 
portfolio formation horizon. We then hold these long and short positions for the following $H$ weeks before the portfolios are rebalanced and a new set of portfolios is formed.

Following Basu and Miffre (2013), we further implement a combined strategy that results from a two-way sort on the positions of hedgers and speculators. The collection of all commodities is split into two equal samples based on the mean hedging pressure of hedgers over the previous $R$ weeks. We thus form a backwardated portfolio (which we term 'Low Hedg ') and a contangoed portfolio ('High $h_{H e d g}$ '). Next, the positions of hedgers are combined with those of speculators by buying the $40 \%$ of Low $_{\text {Hedg }}$ for which speculators had the highest hedging pressure and selling the $40 \%$ of $\mathrm{High}_{\mathrm{Hedg}}$ for which speculators had the lowest hedging pressure over the R-week horizon. As previously, we then hold these long and short positions for the following $H$ weeks before the portfolios are rebalanced and a new set of portfolios is formed. The implicit choice that we made above was to first sort on the hedging pressure of hedgers and then on the hedging pressure of speculators. However, this ordering was entirely arbitrary, so we then repeat the two way sort procedure but now swapping the order of forming the portfolios.

The approaches that we design to capture the trading behavior of hedgers and speculators are identical in all respects except for the sorting method used to form the portfolios. The portfolio formation and holding periods, $R$ and $H$ respectively, are set throughout to 4, 13, 26 or 52 weeks. All possible combinations $(4 \times 4)$ of these four ranking and holding periods leads to a total of 16 long-short portfolios for each of the strategies we described above. For simplicity of presentation, we report the results from a portfolio that equally-weights these 16 combinations of horizons throughout the rest of this paper. ${ }^{13}$ Also, taking our lead from existing research (see, for example, Erb and Harvey, 2006; Miffre and Rallis, 2007), to avoid the strategies being excessively concentrated in a small number of commodities and to ensure reasonable diversification, we also

\footnotetext{
${ }^{13}$ It would be of interest to report the results for a wider range of portfolios but unfortunately the number of possible such portfolios makes this infeasible (we have 16 strategies per signal, four signals used as stand alone, and four signals used in combination, making a total of over 100 possible strategies). We do not have any reason to favour some of these strategies as being more sensible or useful than others and so selecting any individual ones would be entirely arbitrary. In addition, we wish to mimic the behaviour and impact aggregated across all speculators who may have different ranking and holding periods and taking an equally-weighted portfolio will approximately achieve this.
} 
equally-weight the constituents of the long and short portfolios. Finally, the long-short portfolios are conservatively assumed to have a leverage of two - i.e. they are $50 \%$ collateralized. ${ }^{14}$

\subsection{Modeling Conditional Volatility and Conditional Correlation}

To model volatility, we use the generalized autoregressive conditional heteroskedasticity GARCH(1,1) model of Bollerslev (1986). The $\operatorname{GARCH}(1,1)$ variance, $h_{C, t}$, describes the volatility dynamics of a (long, short or long-short) commodity portfolio $C$ as follows

$$
\begin{aligned}
& R_{C, t}=\mu+\varepsilon_{C, t} \\
& h_{C, t}=\gamma+\alpha \varepsilon_{C, t-1}^{2}+\beta h_{C, t-1}
\end{aligned}
$$

$R_{C, t}$ is the time $t$ return of the (long, short or long-short) commodity portfolio modeled in Sections 4.1. and 4.2., $\varepsilon_{C, t}$ are residuals distributed as $N\left(0, h_{C, t}\right), \mu$ is the mean return of $R_{C, t}, \alpha, \beta$ and $\gamma$ are such that $\gamma>0, \alpha \geq 0, \beta \geq 0$ and $\alpha+\beta<1$.

When it comes to modeling the return co-movements between commodities $C$ and traditional assets $T$, we use the dynamic conditional correlation (DCC) model of Engle (2002). ${ }^{15}$ DCC timevarying correlations are estimated in two steps. The first step estimates time-varying variances as $\operatorname{GARCH}(1,1)$ processes and the second step models a time-varying correlation matrix using the standardized residuals from the first-stage estimation. More specifically, the covariance matrix is expressed as $H_{t} \equiv D_{t} R_{t} D_{t}$, where $D_{t}=\operatorname{diag}\left(\sqrt{h_{C, t}}, \sqrt{h_{T, t}}\right)$ is a diagonal matrix of univariate $\operatorname{GARCH}(1,1)$ volatilities and $R_{t}=Q_{t}^{*-1} Q_{t} Q_{t}^{*-1}$ is the time varying correlation matrix, with:

- $\quad Q_{t}=\left(q_{C, T, t}\right)$ as described by $Q_{t}=(1-a-b) \bar{Q}+a\left(\varepsilon_{C, t-1} \varepsilon_{T, t-1}\right)+b Q_{t-1}$, where $\varepsilon_{C, t}=R_{C, t} / \sqrt{h_{C, t}}$ and $\varepsilon_{T, t}=R_{T, t} / \sqrt{h_{T, t}}$ are standardized residuals modeled from the first stage. $\bar{Q}$ is the $N \times N$ unconditional covariance matrix of standardized residuals, and $a$ and $b$ are non-negative coefficients satisfying $a+b<1$,

\footnotetext{
${ }^{14}$ Hedge funds typically opt for considerably higher leverage multiples.

15 See Büyükşahin and Robe (2010), Büyükşahin et al. (2010), Chong and Miffre (2010) for an analysis of conditional correlations between traditional assets and long-only commodity futures.
} 
- $\quad Q_{t}^{*}=\left(q_{i i, t}^{*}\right)=\left(\sqrt{q_{i i, t}}\right)$ is a diagonal matrix composed of the square root of the $i^{\text {th }}$ diagonal elements of $Q_{t}$, where $i$ stands for $C$ or $T$.

Rewriting $R_{t}=Q_{t}^{*-1} Q_{t} Q_{t}^{*-1}$, the time $t$ conditional return correlation between a commodity and traditional asset can then be expressed as

$$
\rho_{C, T, t}=\frac{q_{C, T, t}}{\sqrt{q_{C, t}} \sqrt{q_{T, t}}}
$$

\subsection{Testing for Granger-causality}

Our analysis focuses on the hedging pressure $(H P)$ of speculators, which measures the propensity of speculators to be net long or net short. Essentially, a high HP (e.g., 0.8) translates into large speculators being net long (e.g., $80 \%$ are long and $20 \%$ are short), while a low $H P$ (e.g., 0.2) translates into large speculators being net short (e.g., 20\% are long and $80 \%$ are short). We measure the average hedging pressure of speculators in each week of the holding period for the commodities included in a given (long, short or long-short) commodity portfolio $C$. We denote this quantity $\overline{\mathrm{HP}}_{\mathrm{C}, \mathrm{t}}$ and use $\Delta \overline{\mathrm{HP}}_{\mathrm{C}, \mathrm{t}}$ as a measure of the propensity of speculators to change their

commodity exposure. In the case of a long portfolio, a positive $\Delta \overline{\mathrm{HP}}_{\mathrm{C}, \mathrm{t}}$ means that long speculators increased their long exposure. In the case of a short portfolio, a negative $\Delta_{\mathrm{HP}} \overline{\mathrm{C}}_{\mathrm{t}}$ means that short speculators decreased their long exposures and thus increased their short exposures.

To test whether the increased financialization of commodity markets led to change in volatility, we run tests of the null hypothesis that changes in the hedging pressure of speculators do not Granger-cause changes in the volatility of the long, short and long-short commodity portfolio returns. Namely, the following regression is estimated:

$$
\Delta \sqrt{\mathrm{h}_{\mathrm{C}, \mathrm{t}}}=\delta_{0}+\delta_{1} \Delta \overline{\mathrm{HP}}_{\mathrm{C}, \mathrm{t}-1}+\delta_{2} \Delta \sqrt{\mathrm{h}_{\mathrm{C}, \mathrm{t}-1}}+v_{\mathrm{C}, \mathrm{t}}
$$

$\Delta \sqrt{h_{C, t}}$ measures the change in the annualized conditional volatility of the long (respectively short, respectively long-short) commodity portfolio, $\Delta \overline{\mathrm{HP}}_{c, t-1}$ represents the first lag in the change 
of the average hedging pressure of speculators for the assets included in long (respectively short, respectively long-short) commodity portfolio $C$ over the holding period, $v_{C, t}$ are disturbances and $\delta_{0}, \delta_{1}$ and $\delta_{2}$ are parameters to estimate. The null hypothesis that $\delta_{1}=0$ is then tested using a Granger-causality test, where a rejection of the null indicates that speculators through their long (respectively short, respectively long-short) positions had an impact on volatility. If $\delta_{1}$ is positive and significant for a given long portfolio, then increases in the long positions of speculators (namely, $\Delta \overline{\mathrm{HP}}_{\mathrm{C}, \mathrm{t}-1}>\mathbf{0}$ ) destabilize commodity markets by increasing the volatility of that long portfolio returns. Similarly, if $\delta_{1}$ is negative and significant for a given short portfolio, then increases in the short positions of speculators (namely, $\Delta \overline{\mathrm{HP}}_{\mathrm{C}, \mathrm{t}-1}<\mathbf{0}$ ) destabilize commodity markets by increasing the volatility of the returns of that short portfolio.

Granger-causality tests are also used to investigate whether the financialization of commodity markets had a bearing on conditional correlation. The following regression is estimated for the conditional return correlations between the long, short and long-short commodity portfolios $C$ and the traditional asset class $T$

$$
\Delta \rho_{\mathrm{C}, \mathrm{T}, \mathrm{t}}=\delta_{0}+\delta_{1} \Delta \overline{\mathrm{HP}}_{\mathrm{C}, \mathrm{t}-1}+\delta_{2} \Delta \rho_{C, T, \mathrm{t}-1}+v_{\mathrm{C}, P, t}
$$

We test three sets of null hypotheses. First, that changes in the hedging pressure of speculators for the constituents of the long portfolios in (4) do not Granger-cause a change in the conditional correlation between the returns of the long commodity portfolio and the returns of the traditional asset. Second, that changes in the hedging pressure of speculators for the constituents of the short portfolios in (4) do not Granger-cause a change in the conditional correlation between the returns of the short commodity portfolio and the returns of the traditional asset. Third, that changes in the hedging pressure of speculators for the constituents of the long-short portfolios in (4) do not Granger-cause a change in the conditional correlation between the returns of the long-short commodity portfolio and the returns of the traditional asset. As in equation (3), a positive and significant $\delta_{1}$ in (4) indicates increased integration driven by speculators increasing their long positions. A negative and significant $\delta_{1}$ in (4) indicates increased integration driven by speculators increasing their short positions.

We employ two lag lengths in the tests - a lag of one week but we also (separately) test the joint significance of the lags up to order four in equations (3) and (4). Note that since we consider 
changes in all of the variables rather than their levels in the Granger-causality tests, we can be confident that all of the variables employed are stationary.

Finally, we test the robustness of the results to three different specifications of equations (3) and (4). Following Irwin and Sanders (2011), Brunetti et al. (2011) and Büyükşahin and Robe (2010), the first robustness test uses conditional volatility and conditional correlation as dependent and independent variables in (3) and (4) instead of their changes. As conditional volatilities and correlations do not depend solely on past values and traders' positions, the second robustness test augments equations (3) and (4) with the first lag in two business cycle variables ${ }^{16}$ (in a way similar to Büyükşahin and Robe, 2010). Finally, the third robustness test uses the disaggregated (instead of aggregated) Commitment of Traders report to test the null hypothesis that professional money managers (i.e., CTAs, CPOs and hedge funds) had no destabilizing effect on conditional volatility and correlation.

\section{Empirical Results}

\subsection{Performance of Long-Short Commodity Portfolios}

Table 2 presents a summary of the performances of all of the various trading strategies that we outlined above - including their mean excess returns, a $t$-test for the significance of those returns, their standard deviations, and Sharpe ratios. Results for the momentum and term structure strategies are given in Panel A, those based on hedging pressure are given in Panel B, and finally for comparison Panel C returns similar results for the equally-weighted and S\&P-GSCI long-only portfolios. As stated above, in order to keep the number of results manageable, only the results for a portfolio that equally-weights all possible combinations of the four formation and holding periods are presented.

In summary, Table 2 shows that active long-short strategies are able to significantly outperform a passive, long-only approach. ${ }^{17}$ The mean risk-adjusted performance of the active strategies as

\footnotetext{
16 The business cycle variables considered are the default spread (difference in yields between BAA and AAA-rated bonds) and term spread (difference between 10-year constant maturity Tbond yield and 3-month T-bill rate), where the data are downloaded from the Federal Reserve of St Louis. These are also measured weekly.

${ }^{17}$ We proxy the performance of the average CTA by that of the EDHEC-Risk Institute Global CTA Index. Over the sample January 1997 - March 2011 for which we have CTA data, both our 
measured by the Sharpe ratio is 0.46 for the momentum and term structure group and 0.55 for the hedging pressure group, yet it is a mere 0.05 for the equally-weighted passive portfolio and 0.20 for the S\&P commodity index. These findings serve to further confirm the previously reported need to take on board the degree of backwardation and contango when designing commodity futures trading strategies.

\section{$<$ Insert Table 2 around here >>}

Table 2 also presents slope coefficients from regressions of the hedging pressure of speculators on a time trend for each of the commodity strategies presented in Section 3, where hedging pressure is measured as $\overline{\mathrm{HP}}_{\mathrm{C}, \mathrm{t}}$, i.e., as the cross-sectional average of the hedging pressure of speculators for the constituents of the long-short portfolios over the holding period for the strategy. The idea is to investigate how the average hedging pressure of speculators for the commodity futures included in the long-short portfolios changes over time. An increased level of financialization of commodity markets would translate into an increase in the hedging pressure of speculators for the long-short portfolios over time. This would be consistent with the idea that speculators took more long-short positions at the end of the sample than they did at the beginning, a sign of increased financialization.

The slope coefficients on the time trend reported in Table 2 are for the most part in line with this viewpoint. They are positive and significant at the $1 \%$ level for seven of eight long-short portfolios, confirming the evidence from the perspective of the long-short portfolios of an increased financialization of commodity markets. The question remains, however., as to whether this observed increase in the financialization of commodity futures markets by long-short investors led to an increase in the volatility of commodity markets and to an increase in their conditional correlations with traditional assets. We now turn our attention to these questions.

\subsection{Granger-causality Tests using the Aggregated Commitment of Traders Report}

long-short commodity portfolios and the average CTA substantially outperform long-only benchmarks (the Sharpe ratio of our long-short portfolios equals 0.61 on average, that of the CTA Global benchmark is at 0.55 versus 0.15 for the S\&P-GSCI and -0.02 for the equally-weighted portfolio of all commodities). Thus, as in Table 2 for our long-short portfolios, the average CTA outperforms long-only benchmarks. This comparison should, however, be treated with some caution as unlike the average CTA, we do not take positions in global equity, fixed income and FX markets. 
Results from tests as to whether speculators increase volatility and cross-market linkages are reported in Table 3 for the long, short and long-short portfolios. We present estimates and their associated $t$-statistics (in parentheses) for $\delta_{1}$ in (3) and (4), and $p$-values for the null hypothesis that changes in the hedging pressure of speculators does not Granger-cause changes in either conditional volatility (Panel A) or conditional correlation (Panels B and C). As the data frequency is weekly, we report $p$-values from Granger-causality tests with four lags as well as one (under the headings $p(4)$ and $p(1)$ respectively).

\section{$<$ Insert Table 3 around here $>>$}

Regardless of the panel or portfolio, $\delta_{1}$ is never significant at the $5 \%$ level. This indicates that speculators neither increased nor decreased conditional volatility or conditional correlation. The

$p$-values indicate a failure to reject the null hypothesis of no-causality for all the long portfolios, all but one of the short portfolios, and all the long-short portfolios. This shows that the increased participation of speculators did not increase either the volatility of the portfolios they held or the level of integration of these portfolios with traditional assets. These results go against the idea that speculators destabilized commodity markets or increased asset correlations by treating commodities as part of their strategic and tactical asset allocations.

Two robustness checks are implemented. Following Brunetti et al. (2011) and Büyükşahin and Robe (2010), we test whether our results on the financialization of commodity markets are any different first if we use the level (instead of the change) in conditional volatility and in conditional correlation in (3) and (4); and second, if we include as explanatory variables the first lag in two business cycle variables (the default spread and term spread). The $p$-values from Granger-causality tests, reported on the right-hand side of Table 3 (under the headings Test 1 and Test 2), are all greater than $5 \%$ and thus the results are consistent with those previously reported.

\subsection{Granger-causality Tests using the Disaggregated Commitment of Traders Report}

The analysis conducted thus far focuses on the positions of commercial market participants (hedgers) and non-commercial market participants (speculators) as reported in the Commitment of Traders report. According to the CFTC website, the "commercial" category includes 1. Producers, processors, merchants and users of the underlying commodity (who use commodity derivatives to hedge price risk); and 2. Swap dealers (who hedge their short OTC positions by 
taking long futures positions). The "non-commercial" category includes 1. Professional money managers (CTAs, CPOs and hedge funds); and 2. A wide array of other non-commercial traders not classified as professional money managers (e.g., pension funds with long-only positions). Strictly, swap dealers are not pure hedgers in the sense of Keynes (1930) since they do not have a position in the underlying commodity. Similarly, pension funds and long-only indexers are not pure Keynesian speculators since they merely seek passive exposure to commodity markets as part of their strategic asset allocation.

Bearing these distinctions in mind, the disaggregated Commitment of Traders report (also available from the CFTC website) splits the positions of market participants explicitly into four categories: 1. Pure hedgers (producers, processors, merchants and users of the physical commodity); 2. Swap dealers; 3. Pure speculators (professional money managers such as CTAs, CPOs and hedge funds); and 4. Other non-commercial traders. It is hoped that by omitting other non-commercial traders from the non-commercial category, we will get a better idea of the trades implemented by pure speculators (professional money managers). Similarly, by omitting swap dealers from the commercial category, we will obtain a better picture of pure hedging demand from those who have a commercial interest in the physical commodity. Disaggregated data on the positions of pure hedgers and pure speculators are only available since June 13, 2006, which restricts the ensuing analysis to the period June 2006 - March 2011.

Figure 2 plots the evolution in the S\&P-GSCI (on the right-hand scale) and the evolution in the long and short open interests of professional money managers averaged across our 27 commodities (on the left-hand scale). The long positions have risen sharply and seem to follow the ups and downs of the S\&P-GSCI, legitimizing the concern that changes in the former could have increased volatility. On the other hand, the short positions look as if they remained constant, hovering around 25,000 over the period 2006-2011. As the short positions of professional money managers pretty much remained constant, their change is unlikely to have increased volatility.

<< Insert Figure 2 around here>>

Table 4 presents summary statistics for the performances of long-short and long-only commodity portfolios over the period June 2006 - March 2011. Unlike in Table 2, the asset allocation of the portfolios based on the positions of hedgers or/and speculators is based on the disaggregated hedging pressure of pure hedgers and pure speculators as opposed to the aggregated hedging pressure of commercial and non commercial traders. As in Table 2 however, the results of Table 
4 highlight the importance of taking long, as well as short, positions in commodity futures markets. Over this shorter sample too, the Sharpe ratios of the long-short portfolios systematically and substantially exceed those of the long-only portfolios (which happen to be negative and as low as -0.15 in the case of the S\&P-GSCI). The best performance is achieved within the double-sort portfolio based on the positions of, first, hedgers and, second, speculators, whose equally-weighted portfolio of 16 permutations of ranking and holding periods achieves a Sharpe ratio of 1.19. Table 4 also presents slope coefficients of regressions of the hedging pressure of pure speculators on a time trend for each of the long-short strategies, where the hedging pressure of pure speculators is measured as $\overline{\mathrm{HP}}_{\mathrm{C}, \mathrm{t}}$, namely, as the cross-sectional average of the HP of pure speculators for the constituents of the long-short portfolios over the holding period of the strategy. With only one exception, these slope coefficients are positive and significant at the 5\% level, indicating (as in Table 2 for the longer sample) an increase in the financialization of commodity markets over this shorter period.

$<<$ Insert Table 4 around here >>

Instead of using the aggregated speculators' positions as in Table 3, the positions of pure speculators (i.e., hedge funds) as disclosed in the CFTC disaggregated Commitment of Traders report are tracked in the holding periods of the long-short strategies and the cross-sectional average of these hedging pressures are measured for the constituents of the long-short portfolios. The first lag in the change of these average hedging pressures is then used as a regressor in (3) and (4) to test whether changes in the positions of pure speculators Granger-cause a change in the conditional volatility of the long-short portfolios they hold or a change in the conditional correlation between their portfolios and traditional assets. Table 5 reports tests of these hypotheses for conditional volatilities in Panel A and for conditional correlations in Panels B and C. None of the $\delta_{1}$ coefficients in (3) and (4) are significant even at the $10 \%$ level. With only one exception, the $p$-values for the null hypothesis of no Granger-causality are more than $10 \%$, representing an almost systematic failure to reject the null hypothesis of no Granger-causality. Altogether, these conclusions are robust to the definition of the non-commercial category: whether it focuses exclusively on professional money managers or not, we find very little to no evidence that speculators destabilized commodity markets by increasing the volatility of the portfolios they held or the integration of these portfolios with traditional assets.

\section{$<<$ Insert Table 5 around here $>>$}




\section{Conclusions}

This paper mimics the trading behavior of long-short commodity market participants using a battery of strategies that they are known to follow and tests whether their trading activities have an impact on the volatility of the commodity portfolios they hold or on cross-market correlations. If the presence of long-short commodity speculators is detrimental to the functioning of commodity markets, their trading should Granger-cause a change in the volatility of their portfolios and/or a change in the conditional correlation between their commodity portfolios and traditional assets. This would be a source of concern not only to regulators but to CTAs managers themselves as they would then destroy the very diversification benefits that they sought in the first instance.

Our results find no support for the hypothesis that speculators destabilized commodity prices by increasing volatility or co-movements with traditional assets. Interestingly, this conclusion holds irrespective of whether speculators are labeled as "non-commercial" in the CFTC Commitment of Traders report or as "professional money managers" (i.e., CTAs, CPOs and hedge funds) in the CFTC disaggregated Commitment of Traders report. Thus, long-short speculators can take comfort in knowing that their trades do not alter the risk and diversification properties of their portfolios. It also follows from the analysis presented here that there is no need for concern

relating to the participation of professional money managers in commodity futures markets. If we are looking for the causes of changes in commodity price instability, it seems that we must look elsewhere - and in particular at the fundamental drivers of commodity prices related to global current and expected future growth rates. Instead, it is important to devote more resources to collecting and analyzing inventory data worldwide as this information might be crucial in supporting an understanding of the drivers of volatility in commodity markets which are well rooted in the forces of supply and demand.

While the media and governments courting popular opinion have called for an increase in the regulation of commodity speculators, our research adds to an emerging consensus that speculators do not have a damaging impact on the functioning of commodity markets. There are also concerns that introducing such unnecessary regulation could in itself be damaging. Sanders and Irwin (2011b) argue that attempts to curb speculative activities could reduce market liquidity and depth, and could increase risk premia and hedging costs. It may also lead to the development 
of "off-shore" trading in less regulated jurisdictions or push traders to cash markets where the impacts on the prices of commodities faced by end consumers would be more direct. 


\section{References}

Basu D. and J. Miffre, 2013, Capturing the risk premium of commodity futures: The role of hedging pressure, Journal of Banking and Finance 37, 2652-2664

Bhardwaj, G., G. Gorton and K. G. Rouwenhorst, 2008, Fooling some of the people all of the time: The inefficient performance of commodity trading advisors, Yale ICF Working paper 08-21

Bollerslev, T., 1986, Generalized autoregressive conditional heteroskedasticity, Journal of Econometrics 31, 3, 307-327

Bryant, H. L, D. A. Bessler and M. S. Haigh, 2006, Causality in futures markets, Journal of Futures Markets 26, 11, 1039-1057

Brunetti, C., B. Büyükşahin and J. Harris, 2011, Speculators, prices and market volatility, John Hopkins University, Working paper

Büyükşahin, B. and M. Robe, 2010, Speculators, commodities and cross-market linkages, American University, Working paper

Büyükşahin, B., M. Haigh and M. Robe, 2010, Commodities and equities: Ever a "market of one"?, Journal of Alternative Investments 12, 3, 76-95

Calvo-Gonzalez, O., R. Shankar and R. Trezzi, 2010, Are commodity prices more volatile now: a long-run perspective, World Bank Policy Research Working Paper 5460

Cheng, I-H., A. Kirilencho and W. Xiong, 2012, Convective risk flows in commodity futures markets, Working paper

Chong, J. and J. Miffre, 2010, Conditional correlation and volatility in commodity futures and traditional asset markets, Journal of Alternative Investments 12, 3, 61-75

De Long, B., A. Shleifer, L. Summers and R. Waldmann, 1990, Positive feedback investment strategies and destabilizing rational speculation, Journal of Finance 45, 2, 379-395

Engle, R. F., 2002, Dynamic conditional correlation: A simple class of multivariate generalized autoregressive conditional heteroskedasticity models, Journal of Business and Economic Statistics $20,3,339-350$

Ederington, L. and J. H. Lee, 2002, Who trades futures and how: evidence from the heating oil futures market, Journal of Business 75, 2, 353-373

Erb, C. and C. Harvey, 2006, The strategic and tactical value of commodity futures, Financial Analysts Journal 62, 2, 69-97

Friedman, M., 1953, The case for flexible exchange rates, in Milton Friedman, ed.: Essays in Positive Economics University of Chicago Press, Chicago, Illinois, US

Fuertes, A-M., J. Miffre, and G. Rallis, 2010, Tactical allocation in commodity futures markets: Combining momentum and term structure signals, Journal of Banking and Finance 34, 10, 25302548 
Gilbert, C. L., 2010, How to understand high food prices, Journal of Agricultural Economics 61, 2 , $398-425$

Gilbert, C. L. and C. W. Morgan, 2010, Food price volatility, Philosophical Transactions of the Royal Society B 365, 3023-3034

Gorton, G. and G. Rouwenhorst, 2006, Facts and fantasies about commodity futures, Financial Analysts Journal 62, 2, 47-68

Granger, C. W. J., 1969, Investigating causal relations by econometric models, Econometrica 37 , 424-438

Hailu, G. and A. Weersink, 2010, Commodity price volatility: the impact of commodity index traders CATPRN Commissioned Paper 2010-02

Hamilton, J., 2009, Causes and consequences of the oil shock of 2007-08, Brookings Papers on Economic Activity Spring, 215-259

Irwin, S. H. and D. Sanders, 2011, Index funds, financialization, and commodity futures markets, Applied Economic Perspectives and Policy 33, 1-31

Irwin, S. H. and D. Sanders, 2012, Financialization and structural change in commodity futures markets, Journal of Agricultural and Applied Economics 44, 3, 371-396

Irwin, S. H., D. Sanders and R. P. Merrin, 2009, Devil or angel? The role of speculation in the recent commodity price boom (and bust), Journal of Agricultural and Applied Economics 41, 2, 377-391

Keynes, M., 1930, A Treatise on Money, II: The Applied Theory of Money, Macmillan edition, London

Korniotis, G., 2009, Does speculation affect spot price levels? The case of metals with and without futures markets, Working paper, Federal Reserve Board, Washington, D.C.

Miffre, J. and G. Rallis, 2007, Momentum strategies in commodity futures markets, Journal of Banking and Finance 31, 6, 1863-1886

Sanders, D. R. and S. H. Irwin, 2011a, New evidence on the impact of index funds in US grain futures markets, Canadian Journal of Agricultural Economics 59, 519-532

Sanders, D. R. and S. H. Irwin, 2011b, The impact of index funds in commodity futures markets: A systems approach, Journal of Alternative Investments Summer, 40-49

Sanders, D. R., S. H. Irwin, and R. Merrin, 2010, The adequacy of speculation in agricultural futures markets: Too much of a good thing?, Applied Economic Perspectives and Policy 32, 1, 77-94

Stoll, H. and R. Whaley, 2010, Commodity index investing and commodity futures prices, Journal of Applied Finance 20, 7-46

Tang, K. and W. Xiong, 2012, Index investment and financialization of commodities, Financial Analysts Journal 68, 6, 54-74

Till, H., 2009, Has there been excessive speculation in the US oil futures markets? EDHEC-Risk Institute research paper 


\section{Table 1: Summary Statistics}

The table presents summary statistics for the excess returns of individual commodity futures (Panel A), long-only commodity indices (Panel B) and traditional assets (Panel C). When it comes to excess returns, Mean is the annualized mean excess returns, $t$ (Mean) stands for the associated $t$-statistic in parentheses, $\mathrm{SD}$ is the annualized standard deviation of excess returns, Sharpe is the ratio of the annualized mean to the annualized SD. S\&P-GSCI is the Standard and Poor's Goldman Sachs Commodity Index, and the S\&P500 composite is a broad stock index. The mean open interest is calculated as the average over time of the open interests on the front or second-nearest contracts. The sample period is October 1992 to March 2011. Data frequency is weekly.

\begin{tabular}{|c|c|c|c|c|c|c|}
\hline & \multicolumn{4}{|c|}{ Excess Returns } & \multicolumn{2}{|c|}{ Open interest } \\
\hline & Mean & $t($ Mean) & SD & Sharpe & Mean & SD \\
\hline \multicolumn{7}{|l|}{ Panel A: Individual Commodity Futures } \\
\hline Cocoa & 0.0158 & $(0.22)$ & 0.3053 & 0.0519 & 29,233 & 22,647 \\
\hline Coffee C & 0.0101 & $(0.11)$ & 0.3825 & 0.0264 & 33,633 & 28,018 \\
\hline Copper grade \# 1 & 0.0878 & $(1.39)$ & 0.2712 & 0.3238 & 13,319 & 16,594 \\
\hline Corn & -0.0577 & $(-0.91)$ & 0.2714 & -0.2125 & 217,261 & 167,378 \\
\hline Cotton \# 2 & -0.0137 & $(-0.22)$ & 0.2705 & -0.0508 & 33,191 & 35,958 \\
\hline Crude oil (light sweet) & 0.0918 & $(1.18)$ & 0.3343 & 0.2746 & 161,460 & 91,763 \\
\hline Electricity & -0.2569 & $(-1.52)$ & 0.4477 & -0.5738 & 2,235 & 888 \\
\hline Feeder cattle & 0.0298 & $(0.88)$ & 0.1447 & 0.2058 & 7,898 & 4,446 \\
\hline Frozen concentrated orange juice & -0.0621 & $(-0.84)$ & 0.3191 & -0.1946 & 12,823 & 6,479 \\
\hline Gasoline (Blendstock RBOB) & 0.0452 & $(0.27)$ & 0.3847 & 0.1175 & 54,401 & 28,559 \\
\hline Gold & 0.0427 & $(1.13)$ & 0.1631 & 0.2617 & 108,846 & 91,539 \\
\hline Heating oil \# 2 & 0.0744 & $(1.00)$ & 0.3207 & 0.2321 & 43,491 & 18,784 \\
\hline Lean hogs & -0.0602 & $(-0.99)$ & 0.2615 & -0.2302 & 27,765 & 24,873 \\
\hline Live cattle & 0.0066 & $(0.19)$ & 0.1517 & 0.0433 & 56,973 & 36,524 \\
\hline Natural gas & -0.1618 & $(-1.48)$ & 0.4686 & -0.3452 & 59,756 & 43,832 \\
\hline Oats & -0.0199 & $(-0.27)$ & 0.3187 & -0.0624 & 5,955 & 3,090 \\
\hline Palladium & 0.0986 & $(1.22)$ & 0.3483 & 0.2830 & 7,007 & 6,140 \\
\hline Platinum & 0.0940 & $(1.88)$ & 0.2149 & 0.4373 & 11,821 & 7,484 \\
\hline Pork bellies & 0.0279 & $(0.35)$ & 0.3439 & 0.0812 & 2,555 & 1,956 \\
\hline Random length lumber & -0.1255 & $(-1.67)$ & 0.3232 & -0.3884 & 2,709 & 1,664 \\
\hline Rough rice & -0.0918 & $(-1.13)$ & 0.2723 & -0.3372 & 4,618 & 3,211 \\
\hline Silver & 0.0855 & $(1.27)$ & 0.2894 & 0.2954 & 51,021 & 23,392 \\
\hline Soybean meal & 0.1087 & (1.71) & 0.2731 & 0.3979 & 38,963 & 21,858 \\
\hline Soybean oil & 0.0065 & $(0.12)$ & 0.2367 & 0.0275 & 48,655 & 38,297 \\
\hline Soybeans & 0.0550 & $(0.98)$ & 0.2407 & 0.2287 & 86,780 & 67,679 \\
\hline Sugar \# 11 & 0.0539 & $(0.74)$ & 0.3151 & 0.1711 & 142,656 & 108,928 \\
\hline Wheat & -0.0789 & $(-1.19)$ & 0.2850 & -0.2767 & 81,120 & 67,494 \\
\hline Average & 0.0002 & & 0.2948 & 0.0292 & & \\
\hline \multicolumn{7}{|l|}{ Panel B: Long-Only Commodity Indices } \\
\hline Equally-weighted long-only portfolio & 0.0064 & $(0.23)$ & 0.1208 & 0.0529 & 50,552 & 25,281 \\
\hline S\&P-GSCl & 0.0428 & $(0.84)$ & 0.2178 & 0.1965 & 12,587 & 9,738 \\
\hline \multicolumn{7}{|l|}{ Panel C: Traditional Asset Classes } \\
\hline S\&P-500 composite index & 0.0421 & $(1.03)$ & 0.1755 & 0.2401 & & \\
\hline Barclays Capital US aggregate bond index & 0.0295 & $(2.85)$ & 0.0444 & 0.6631 & & \\
\hline
\end{tabular}




\section{Table 2: The Performance of Long-Short and Long-Only Commodity Portfolios}

The table presents summary statistics for long-short and long-only commodity portfolios. Strategies based on momentum and/or term structure signals are presented in Panel A; strategies based on hedging pressure in Panel $\mathrm{B}$ where the signals are modeled over four ranking periods, $R$, of 4, 13, 26 and 52 weeks. The long-short portfolios are then held over four holding periods, $H$, of 4, 13, 26 and 52 weeks. Instead of reporting summary statistics for each of the 16 portfolios that results from combinations of these $R$ and $H$, a portfolio that equally-weights all 16 combinations is formed for each strategy. The table presents summary statistics for the excess returns of these equally-weighted portfolios. The Mean has been annualized, SD is the annualized standard deviation of the portfolio excess returns, Sharpe is the ratio of Mean to SD, Trend $(\times 100)$ is $100 \times$ the slope coefficient of a regression of the portfolio hedging pressure on a time trend. $t($.$) in parentheses stands for the$ associated $t$-statistic. EW represents an equally-weighted portfolio that includes all 27 commodities. The sample period is October 1992 to March 2011.

\begin{tabular}{|c|c|c|c|c|c|c|}
\hline & Mean & $t$ (Mean) & SD & $\begin{array}{c}\text { Sharpe } \\
\text { ratio }\end{array}$ & $\begin{array}{l}\text { Trend } \\
(\times 100) \\
\end{array}$ & $t($ Trend $)$ \\
\hline \multicolumn{7}{|c|}{ Panel A: Long-Short Portfolios Based on Momentum and/or Term Structure } \\
\hline Momentum & 0.0416 & (1.17) & 0.1536 & 0.2711 & -0.0001 & $(-0.09)$ \\
\hline Term structure & 0.0803 & $(2.02)$ & 0.1712 & 0.4693 & 0.0170 & $(14.87)$ \\
\hline Momentum-TS & 0.0843 & (2.39) & 0.1518 & 0.5556 & 0.0094 & $(9.87)$ \\
\hline TS-Momentum & 0.0898 & $(2.44)$ & 0.1584 & 0.5666 & 0.0079 & $(7.72)$ \\
\hline Average & 0.0740 & & 0.1588 & 0.4656 & & \\
\hline \multicolumn{7}{|c|}{ Panel B: Long-Short Portfolios Based on Hedging Pressure } \\
\hline Hedgers & 0.1140 & $(2.71)$ & 0.1809 & 0.6302 & 0.0134 & $(11.13)$ \\
\hline Speculators & 0.0835 & (2.09) & 0.1717 & 0.4863 & 0.0141 & (12.54) \\
\hline Hedgers-Speculators & 0.0784 & $(2.05)$ & 0.1647 & 0.4759 & 0.0130 & (11.44) \\
\hline Speculators-Hedgers & 0.1086 & $(2.66)$ & 0.1753 & 0.6197 & 0.0141 & (11.99) \\
\hline Average & 0.0961 & & 0.1731 & 0.5530 & & \\
\hline \multicolumn{7}{|c|}{ Panel C: Long-Only Portfolios } \\
\hline EW & 0.0064 & $(0.23)$ & 0.1208 & 0.0529 & & \\
\hline S\&P-GSCI & 0.0428 & $(0.84)$ & 0.2178 & 0.1965 & & \\
\hline
\end{tabular}




\section{Table 3: Granger-causality Tests}

The table tests whether changes in the positions of speculators Granger-cause changes in the volatility of commodity portfolios (Panel A) or changes in the conditional correlation between commodities and traditional asset returns (Panels B and C). $\delta_{1}$ is the slope coefficient of a regression of the change in these conditional volatilities (correlations) on the first lag of the change in the hedging pressure of speculators for the constituents of that specific commodity portfolio. $t$-statistics are in parentheses. $p(n)$ is the $p$-value associated with test of the hypothesis that change in the positions of speculators do not Granger-cause change in volatility (correlation), $n$ is the number of lags. The last two columns present $p$-values from two Granger-causality tests with four lags as robustness tests; the first test uses the levels of, instead of the changes in, conditional volatility and conditional correlation as dependent and independent variables in (3) and (4). The second test augments (3) and (4) with the first lag of default spread and term spread. The sample period is October 1992 to March 2011.

\begin{tabular}{|c|c|c|c|c|c|c|c|c|c|c|c|c|c|c|}
\hline & \multicolumn{4}{|c|}{ Long portfolios } & \multicolumn{4}{|c|}{ Short portfolios } & \multicolumn{4}{|c|}{ Long-short portfolios } & \multirow{2}{*}{ Test 1} & \multirow{2}{*}{ Test 2} \\
\hline & $\delta_{1}$ & & $p(1)$ & $p(4)$ & $\delta$ & & $p(1)$ & $p(4)$ & $\delta_{1}$ & & $p(1)$ & $p(4)$ & & \\
\hline \multicolumn{15}{|c|}{ Panel A: Conditional volatility } \\
\hline Momentum & 0.0036 & $(0.21)$ & 0.83 & 0.58 & -0.0087 & $(-0.78)$ & 0.44 & 0.90 & 0.0074 & $(1.55)$ & 0.12 & 0.43 & 0.54 & 0.43 \\
\hline Term structure (TS) & -0.0132 & $(-0.78)$ & 0.43 & 0.94 & -0.0054 & $(-0.72)$ & 0.47 & 0.43 & 0.0005 & $(0.07)$ & 0.95 & 0.82 & 0.87 & 0.78 \\
\hline Momentum-TS & -0.0066 & $(-0.62)$ & 0.54 & 0.62 & 0.0036 & $(0.58)$ & 0.56 & 0.76 & -0.0004 & $(-0.04)$ & 0.97 & 0.97 & 0.87 & 0.79 \\
\hline TS-Momentum & -0.0097 & $(-0.65)$ & 0.52 & 0.68 & 0.0033 & $(0.39)$ & 0.70 & 0.65 & -0.0030 & $(-0.40)$ & 0.69 & 0.80 & 0.65 & 0.47 \\
\hline Hedgers & -0.0125 & $(-0.77)$ & 0.44 & 0.71 & -0.0077 & $(-0.99)$ & 0.32 & 0.79 & 0.0079 & $(0.93)$ & 0.35 & 0.79 & 0.98 & 0.97 \\
\hline Speculators & 0.0055 & $(0.35)$ & 0.72 & 0.81 & -0.0003 & $(-0.03)$ & 0.98 & 1.00 & 0.0115 & $(1.25)$ & 0.21 & 0.46 & 0.79 & 0.79 \\
\hline Hedgers-Speculators & -0.0074 & $(-0.59)$ & 0.55 & 0.60 & 0.0059 & $(0.70)$ & 0.48 & 0.84 & -0.0014 & $(-0.19)$ & 0.85 & 0.99 & 0.98 & 0.99 \\
\hline Speculators-Hedgers & -0.0117 & $(-0.87)$ & 0.39 & 0.64 & 0.0071 & $(1.16)$ & 0.25 & 0.66 & -0.0032 & $(-0.50)$ & 0.61 & 0.93 & 0.94 & 0.94 \\
\hline \multicolumn{15}{|c|}{ Panel B: Conditional correlation with S\&P500 index } \\
\hline Momentum & -0.0270 & $(-0.64)$ & 0.52 & 0.52 & 0.0071 & $(0.40)$ & 0.69 & 0.04 & -0.0188 & $(-0.79)$ & 0.43 & 0.59 & 0.60 & 0.59 \\
\hline TS & -0.0043 & $(-0.19)$ & 0.85 & 0.06 & 0.0248 & $(0.80)$ & 0.43 & 0.88 & 0.0183 & (1.68) & 0.09 & 0.09 & 0.16 & 0.09 \\
\hline Momentum-TS & 0.0437 & $(1.25)$ & 0.21 & 0.60 & 0.0290 & (1.17) & 0.24 & 0.51 & -0.0137 & $(-0.63)$ & 0.53 & 0.32 & 0.60 & 0.59 \\
\hline TS-Momentum & 0.0180 & $(0.57)$ & 0.57 & 0.81 & 0.0059 & $(0.21)$ & 0.83 & 0.23 & 0.0063 & (1.07) & 0.28 & 0.70 & 0.46 & 0.46 \\
\hline Hedgers & -0.0144 & $(-0.32)$ & 0.75 & 0.06 & 0.0352 & (1.41) & 0.16 & 0.09 & 0.0053 & $(0.26)$ & 0.80 & 0.59 & 0.31 & 0.32 \\
\hline Speculators & -0.0187 & $(-0.42)$ & 0.67 & 0.26 & 0.0195 & $(0.85)$ & 0.40 & 0.08 & 0.0014 & $(0.05)$ & 0.96 & 0.46 & 0.75 & 0.70 \\
\hline Hedgers-Speculators & 0.0331 & $(0.96)$ & 0.34 & 0.58 & 0.0118 & $(0.43)$ & 0.67 & 0.42 & 0.0135 & $(1.58)$ & 0.11 & 0.42 & 0.44 & 0.42 \\
\hline Speculators-Hedgers & 0.0688 & $(1.62)$ & 0.11 & 0.49 & 0.0149 & $(0.60)$ & 0.55 & 0.12 & -0.0001 & $(-0.01)$ & 0.99 & 0.78 & 0.82 & 0.78 \\
\hline \multicolumn{15}{|c|}{ Panel C: Conditional correlation with Barclays bond index } \\
\hline Momentum & 0.0033 & $(0.26)$ & 0.79 & 0.26 & -0.0043 & $(-0.45)$ & 0.65 & 0.89 & -0.0034 & $(-0.37)$ & 0.71 & 0.95 & 0.86 & 0.95 \\
\hline TS & -0.0094 & $(-0.20)$ & 0.84 & 0.61 & -0.0034 & $(-0.35)$ & 0.72 & 0.92 & 0.0162 & $(0.44)$ & 0.66 & 0.95 & 1.00 & 0.94 \\
\hline Momentum-TS & 0.0116 & $(0.60)$ & 0.55 & 0.89 & 0.0055 & $(0.70)$ & 0.48 & 0.84 & -0.0034 & $(-0.74)$ & 0.46 & 0.71 & 0.87 & 0.87 \\
\hline TS-Momentum & 0.0040 & $(0.20)$ & 0.85 & 0.99 & 0.0071 & $(0.62)$ & 0.54 & 0.97 & -0.0361 & $(-0.76)$ & 0.45 & 0.83 & 0.61 & 0.74 \\
\hline Hedgers & -0.0077 & $(-0.18)$ & 0.86 & 0.86 & -0.0001 & $(-0.02)$ & 0.98 & 0.93 & 0.0046 & $(0.21)$ & 0.83 & 0.87 & 0.68 & 0.72 \\
\hline Speculators & -0.0055 & $(-0.24)$ & 0.81 & 0.76 & -0.0033 & $(-0.75)$ & 0.45 & 0.84 & -0.0060 & $(-0.53)$ & 0.60 & 0.74 & 0.93 & 0.83 \\
\hline Hedgers-Speculators & 0.0040 & $(0.18)$ & 0.86 & 0.87 & 0.0060 & $(0.23)$ & 0.82 & 0.94 & -0.0070 & $(-0.96)$ & 0.33 & 0.55 & 0.67 & 0.55 \\
\hline Speculators-Hedgers & 0.0212 & $(0.82)$ & 0.41 & 0.80 & 0.0042 & $(0.57)$ & 0.57 & 0.97 & -0.0023 & $(-0.39)$ & 0.69 & 0.54 & 0.41 & 0.56 \\
\hline
\end{tabular}


Table 4: Performance of Long-Short Commodity Portfolios: Evidence from the Disaggregated Commitment of Traders Report

The positions of pure hedgers (i.e., producers, processors, merchants and users of the underlying commodity) and of pure speculators (i.e., CTAs, CPOs, and hedge funds) as disclosed in the CFTC disaggregated Commitment of Traders report are used to model the performance of the hedgers and speculators-based portfolios. The table presents summary statistics for long-short and long-only commodity portfolios over the period for which the disaggregated Commitment of Traders report data are available: July, 142006 - March, 25 2011. Strategies are based on momentum and/or term structure in Panel A and on hedging pressure in Panel B, where the signals are modeled over ranking periods, $R$, of 4, 13, 26 and 52 weeks. The long-short portfolios are then held over four holding periods, $H$, of 4, 13, 26 and 52 weeks. Instead of reporting summary statistics for each of the 16 portfolios that results from combinations of these $R$ and $H$, a portfolio that equally-weights all 16 combinations is formed for each strategy. The table presents summary statistics for the excess returns of these equally-weighted portfolios. The Mean has been annualized, SD is the annualized standard deviation of the portfolio excess returns, Sharpe is the ratio of Mean to SD, Trend $(\times 100)$ is $100 \times$ the slope coefficient of a regression of the portfolio hedging pressure on a time trend. $t($.$) in parentheses stands for the associated t$-statistic. EW represents an equallyweighted portfolio that includes all 27 commodities.

\begin{tabular}{|c|c|c|c|c|c|c|}
\hline & Mean & $t$-stat & SD & $\begin{array}{c}\text { Sharpe } \\
\text { ratio }\end{array}$ & $\begin{array}{l}\text { Trend } \\
(\times 100) \\
\end{array}$ & $t($ Trend) \\
\hline \multicolumn{7}{|c|}{ Panel A: Long-Short Momentum and/or Term Structure Portfolios } \\
\hline Momentum & 0.0529 & $(0.69)$ & 0.1659 & 0.3190 & 0.0281 & $(5.00)$ \\
\hline Term structure (TS) & 0.0488 & $(0.56)$ & 0.1908 & 0.2556 & 0.0912 & $(16.02)$ \\
\hline Momentum-TS & 0.0910 & (1.19) & 0.1660 & 0.5483 & 0.0598 & $(10.72)$ \\
\hline TS-Momentum & 0.0931 & (1.19) & 0.1707 & 0.5457 & 0.0558 & $(8.96)$ \\
\hline Average & 0.0715 & & 0.1734 & 0.4171 & & \\
\hline \multicolumn{7}{|c|}{ Panel B: Long-Short Hedging Pressure Portfolios } \\
\hline Hedgers & 0.1129 & $(1.11)$ & 0.2212 & 0.5104 & 0.0186 & $(2.25)$ \\
\hline Speculators & 0.1856 & $(2.23)$ & 0.1813 & 1.0235 & 0.0229 & $(2.78)$ \\
\hline Hedgers-Speculators & 0.2210 & (2.59) & 0.1857 & 1.1903 & -0.0065 & $(-1.00)$ \\
\hline Speculators-Hedgers & 0.2131 & $(2.45)$ & 0.1888 & 1.1285 & 0.0122 & $(2.32)$ \\
\hline Average & 0.1832 & & 0.1943 & 0.9632 & & \\
\hline \multicolumn{7}{|c|}{ Panel C: Long-Only Portfolios } \\
\hline EW & -0.0050 & $(-0.06)$ & 0.1781 & -0.0282 & & \\
\hline S\&P-GSCI & -0.0427 & $(-0.33)$ & 0.2841 & -0.1502 & & \\
\hline
\end{tabular}


Table 5: Granger-causality Tests: Evidence from the Disaggregated Commitment of Traders Report

The positions of pure hedgers (i.e., producers, processors, merchants and users of the underlying commodity) and of pure speculators (i.e., CTAs, CPOs, and hedge funds) as disclosed in the CFTC disaggregated Commitment of Traders report are used to model the performance of the hedger- and speculator-based portfolios and subsequently to test for Granger-causality between changes in conditional volatility (correlation) and changes in the positions of pure speculators. $\delta_{1}$ is the slope coefficient of regressions of the change in conditional volatility (correlation) on the first lag of the change in the hedging pressure of the pure speculators for the constituents of that specific commodity portfolio. $p(n)$ is the associated $p$-value when $n$ lags are considered in the Grangercausality tests. The sample covers the period: July, 142006 - March, 25 2011, for which data from the disaggregated Commitment of Traders report are available.

\begin{tabular}{|c|c|c|c|c|}
\hline & \multicolumn{2}{|c|}{$\delta_{1}$} & $p(1)$ & $p(4)$ \\
\hline \multicolumn{5}{|c|}{ Panel A: Conditional Volatility of Commodity Portfolios } \\
\hline Momentum & -0.0344 & $(-1.59)$ & 0.11 & 0.26 \\
\hline Term structure (TS) & -0.0011 & $(-0.03)$ & 0.98 & 0.19 \\
\hline Momentum-TS & 0.0117 & $(0.53)$ & 0.60 & 0.74 \\
\hline TS-Momentum & -0.0056 & $(-0.16)$ & 0.87 & 1.00 \\
\hline Hedgers & 0.0032 & $(0.20)$ & 0.84 & 0.42 \\
\hline Speculators & 0.0057 & $(0.28)$ & 0.78 & 0.30 \\
\hline Hedgers-Speculators & -0.0269 & $(-0.24)$ & 0.81 & 0.45 \\
\hline Speculators-Hedgers & -0.0040 & $(-0.25)$ & 0.80 & 0.01 \\
\hline \multicolumn{5}{|c|}{ Panel B: Conditional Correlation with the S\&P-500 Index } \\
\hline Momentum & -0.1508 & $(-1.15)$ & 0.25 & 0.79 \\
\hline TS & 0.0941 & $(1.17)$ & 0.24 & 0.81 \\
\hline Momentum-TS & -0.0176 & $(-0.20)$ & 0.84 & 0.85 \\
\hline TS-Momentum & -0.0445 & $(-0.42)$ & 0.68 & 0.99 \\
\hline Hedgers & -0.0435 & $(-0.31)$ & 0.75 & 0.50 \\
\hline Speculators & -0.0759 & $(-0.89)$ & 0.37 & 0.65 \\
\hline Hedgers-Speculators & -0.1560 & $(-1.28)$ & 0.20 & 0.41 \\
\hline Speculators-Hedgers & -0.1240 & $(-1.15)$ & 0.25 & 0.73 \\
\hline \multicolumn{5}{|c|}{ Panel C: Conditional Correlation with Barclays Aggregate Bond Index } \\
\hline Momentum & 0.0025 & $(0.94)$ & 0.35 & 0.64 \\
\hline TS & -0.1823 & $(-1.06)$ & 0.29 & 0.69 \\
\hline Momentum-TS & 0.0739 & $(0.70)$ & 0.48 & 0.91 \\
\hline TS-Momentum & 0.0052 & $(0.34)$ & 0.74 & 0.99 \\
\hline Hedgers & 0.0111 & $(0.56)$ & 0.58 & 0.88 \\
\hline Speculators & 0.0002 & $(0.57)$ & 0.57 & 0.89 \\
\hline Hedgers-Speculators & -0.1212 & $(-0.60)$ & 0.55 & 0.30 \\
\hline Speculators-Hedgers & -0.1223 & $(-0.77)$ & 0.44 & 0.73 \\
\hline
\end{tabular}




\section{Figure 1: Open Interest of Non-Commercial Traders}

The figure presents the evolution of the average open interests of traders who are self-classified as noncommercial (i.e. speculators) over the sample period October 1992 to March 2011 (left-hand scale). The series is computed by taking the cross-sectional average of the long (short) open interests of 27 commodities. For comparison, we also plot the value of the S\&P-GSCI (right-hand scale) over the same sample period.

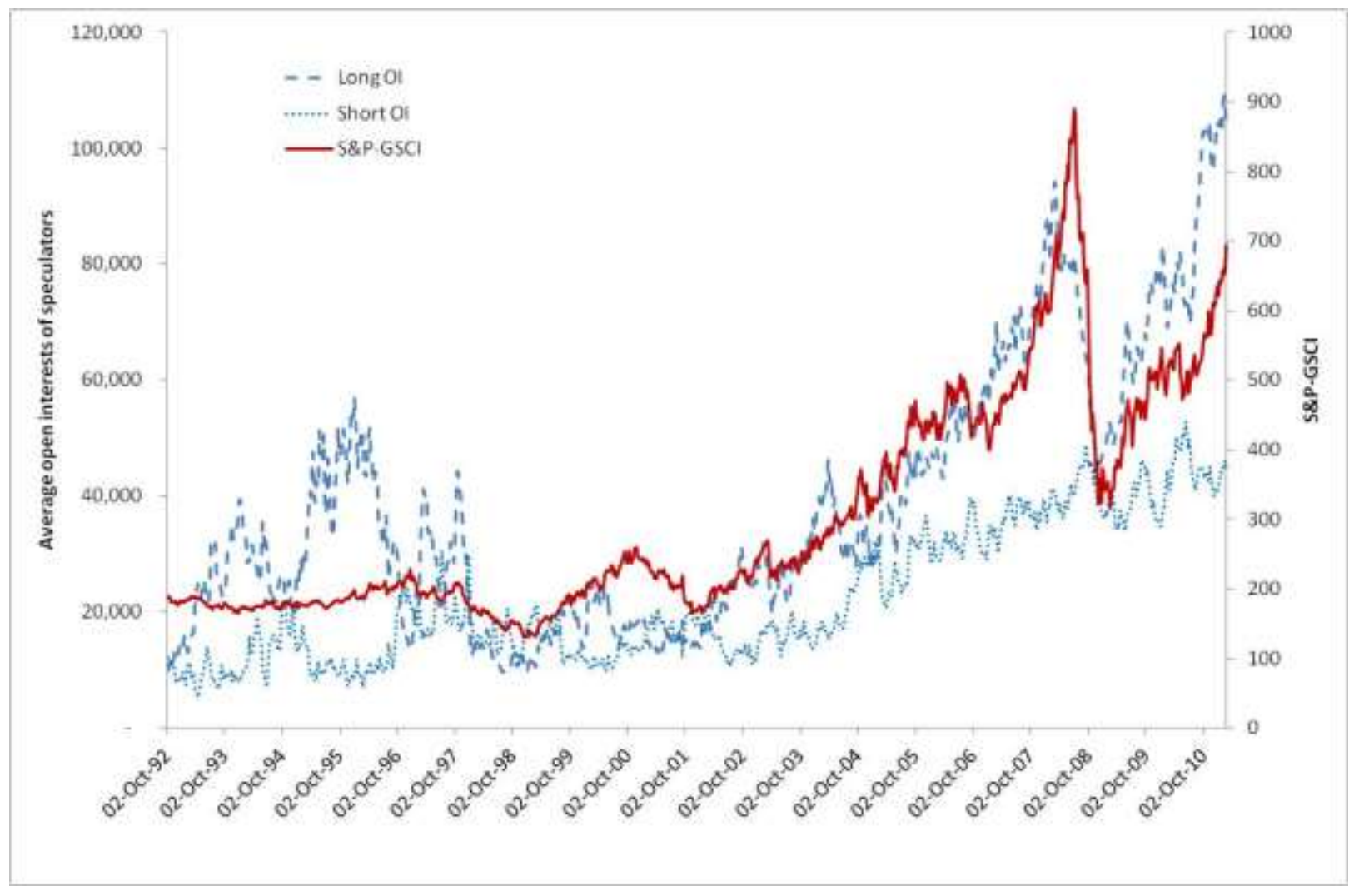




\section{Figure 2: Open Interest of Professional Money Managers}

The figure presents the evolution of the average open interests of traders who are self-classified as professional money managers (CTAs, CPOs and hedge funds) over the sample period July 2006 - March 2011 (left-hand scale). The series is computed by taking the cross-sectional average of the long (short) open interests of 27 commodities. For comparison, we also plot the value of the S\&P-GSCI (right-hand scale) over the same sample period.

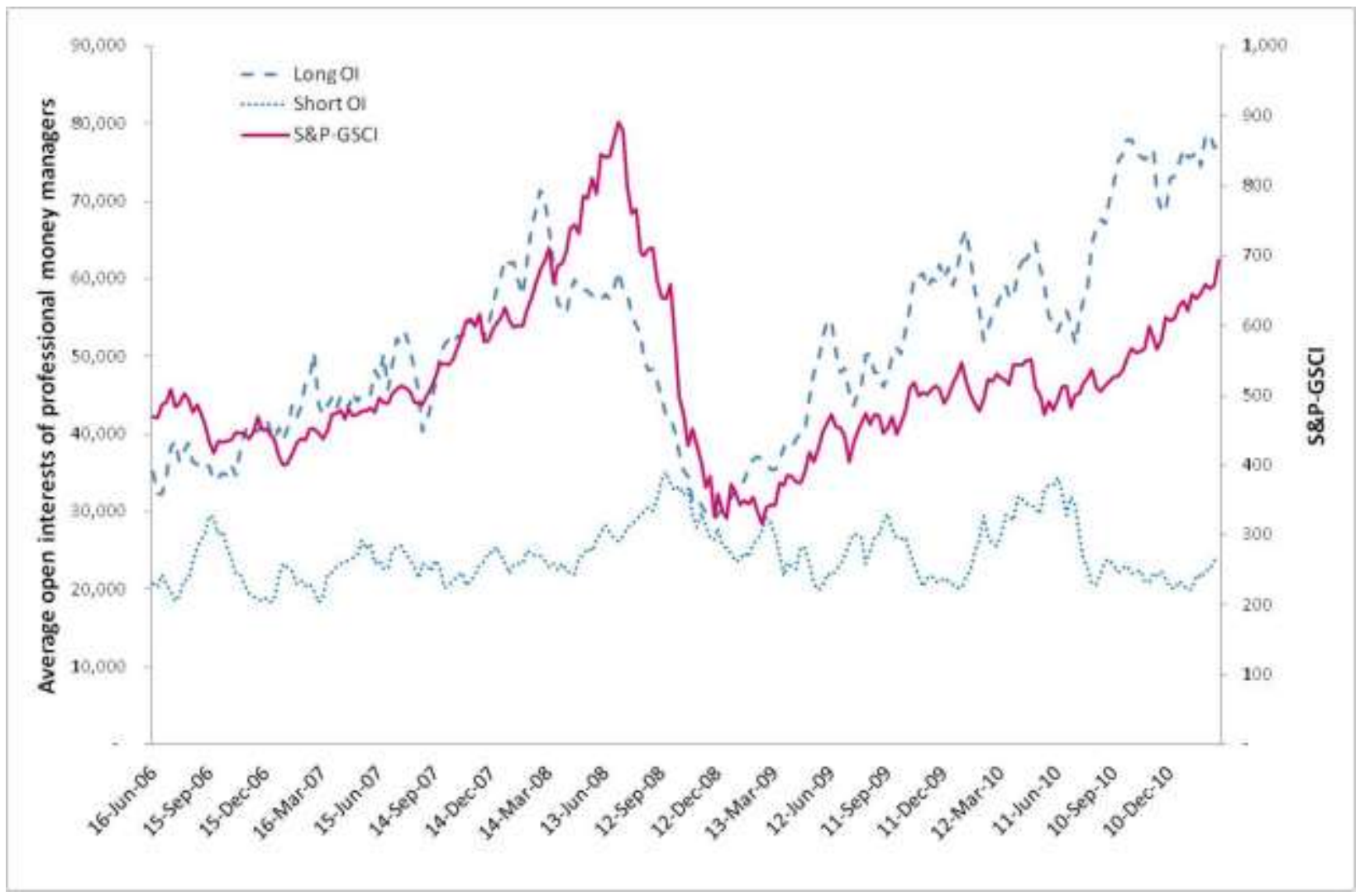

